\title{
Ecology and Biodiversity of Proposed Residential Project at Village Waddhamna, Nagpur, Maharashtra
}

\author{
Umesh Kulkarni, Manali Chalke, and Rochelle Lobo
}

\begin{abstract}
Fine envirotech engineers (FEE), Mumbai, India are environment consultants providing multidisciplinary advice on a wide range of strategic and project specific environmental and sustainable issues. Nagpur Housing \& Area development, a state government administrative authority, proposes to develop a residential Township in village Waddhamna, Nagpur, India. FEE has been entrusted the job of conducting EIA and Environment monitoring planning (EMP). The project aims at converting the existing land into environmental friendly sustainable township without disturbing the present population and trying to conserve existing ecology and biodiversity. The existing development is spread over a total plot Area of 90, 879.89 sq.mt. The proposed scheme consists of 1653 apartments of which 1625 apartments are to be used for residential purpose and 56 apartments are to be used for commercial purpose.

Environmental Monitoring Plan for the proposed project involved looking at an array of impacts the project was expected to have at the proposed site. The impacts are listed further on in the paper.

This paper will discuss in detail the ecological status for the proposed infrastructure project. The study was commissioned to review the existing natural ecology and biodiversity element in the Core Area and surrounding region (Buffer Area). The objective was to provide an assessment of present status of flora, fauna and ecological habitat in the site, comment upon the ecological richness, assess the importance of ecologically important or rare variety of floral and faunal species and evaluate possible direct or indirect impact of the project on ecology - biodiversity and suggest relevant mitigation measures.
\end{abstract}

Index Terms-Core Area, Buffer Area, ecology, biodiversity.

\section{INTRODUCTION}

Biodiversity refers to the diversity of biological organisms, plants and animals in a specific region [1]. Though the fact remains that biodiversity can never be entirely assessed using a single method, it has led to quick, exhilarating and sometimes startling discoveries [2]. Concerns have been established worldwide about the future environment and its resources and discussions are undertaken over achieving the inter and intra generational sustainability [3]. This discussion has covered issues such as, population, agriculture and biodiversity, industry and energy consumption, pollution and global warming and urbanism [3]. While all these issues are interrelated and important, the problem of Urbanism is the one that posses challenge [4]. Sustainability has however started to have considerable influence on planning and policy [5]. Urban sustainability requires balance between social,

Manuscript received August 27, 2014; revised January 5, 2015.

The authors are with the Fine Envirotech Engineers, India (e-mail: uskvuk@gmail.com, rochelle@fineenvirotech.com,druskul@gmail.com). environmental and economical concerns and its development requires focusing on aspects such as the population, land usage and urban structure [6].

Nagpur Housing \& Area development, a state government administrative authority, proposes to develop a residential Township in village Waddhamna, Nagpur, India. It is understood that the overall project development shall increase the human interference in the area. Fine Envirotech Engineers have been entrusted the job of conducting EIA and Environment Monitoring Planning. Environmental Monitoring Plan for the afore mentioned project includes looking at an array of impacts the project is expected to have. They are Air pollution control and management, Noise Control and management, water conservation, Sewage Treatment, Storm Water Management, Solid and E waste management, Energy conservation, Use of Non conventional Energy, Traffic Management, Plantation, Landscaping and Land Management, Management of social issues occupational Safety and Health issues, Environmental Monitoring, Emergency response Plans for emergency scenarios and Environmental management System.

Increase human interference thereby increases the impact on the ecology and biodiversity of the proposed area. Ecological impact in here is defined as "any and all changes in the structure and function of the ecosystem". This paper will discuss in detail the ecological status in an area of $10 \mathrm{~km}$ radius around the proposed infrastructure project. The study was initiated to review the existing natural ecology and biodiversity element in the Core Area and surrounding region (Buffer Area). The objective was to provide an assessment of present status of flora, fauna and ecological habitat in the site, comment upon the ecological richness, assess the importance of ecologically important or rare variety of floral and faunal species and evaluate possible direct or indirect impact of the project on ecology-biodiversity and suggest relevant mitigation measures.

\section{THE SITE}

The proposed site is located in the central part of the country (Latitude: 21 $1^{\circ} 7^{\prime} 58.35^{\prime \prime} \mathrm{N}$; Longitude: 78 56'46.19”E), Waddhamna, Nagpur, Maharashtra. It's stretched over an area of 23 acres and is dominated by teak plantation and surrounded by agricultural land and urbanized area.

Fig. 1 shows the Site under consideration.

\section{PRojeCt Benefits}

This project will include a total of 1653 units of which 
1625 are to be used for residential purpose and 28 for commercial purpose. At present, the proposed site is an open ground. The development at this site is essential in order to improve the aesthetics while transforming it into an environment friendly township. This would in turn create temporary employment opportunities while the construction is on and permanently after the development. This development aims at setting an example of sustainable residential development project by abiding the regulations set by Ministry of Environment and Forest (MoEF), Government of India.

\section{ECOLOGY AND BIODIVERSITY AT WADDHAMNA}

Multiple sampling locations were selected in order to collect data of the overall landscape in the radius of $10 \mathrm{~km}$ around the site under consideration. The sampling locations were strategically selected in all directions to cover all major representative vegetation patterns, faunal and habitat diversity.

Fig. 2 represents the sampling locations for the site under consideration.

In the figure above, the outermost circle shows the sampling points that were located in the radius of $5-10 \mathrm{~km}$ from the proposed site. The middle concentric circle shows the sampling points that were located in the radius of $1-5 \mathrm{~km}$ from the proposed site. The innermost concentric circle shows the sampling points that were located in the radius of $0-1 \mathrm{~km}$ from the proposed site.

In order to assess the local flora and fauna at the proposed site, we resorted to measures such as the species identification, analysis of rare-endangered-threatened species, direct observation, literature study and photo documentation. Tools such as GIS and Diversity Indexes' were used to get graphical output of the findings.

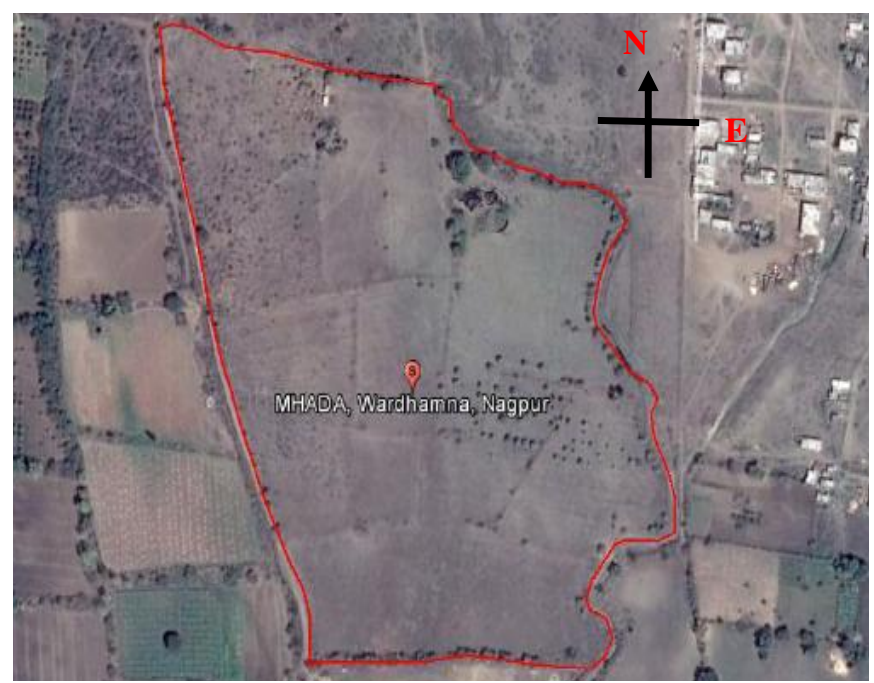

Fig. 1. The project site.

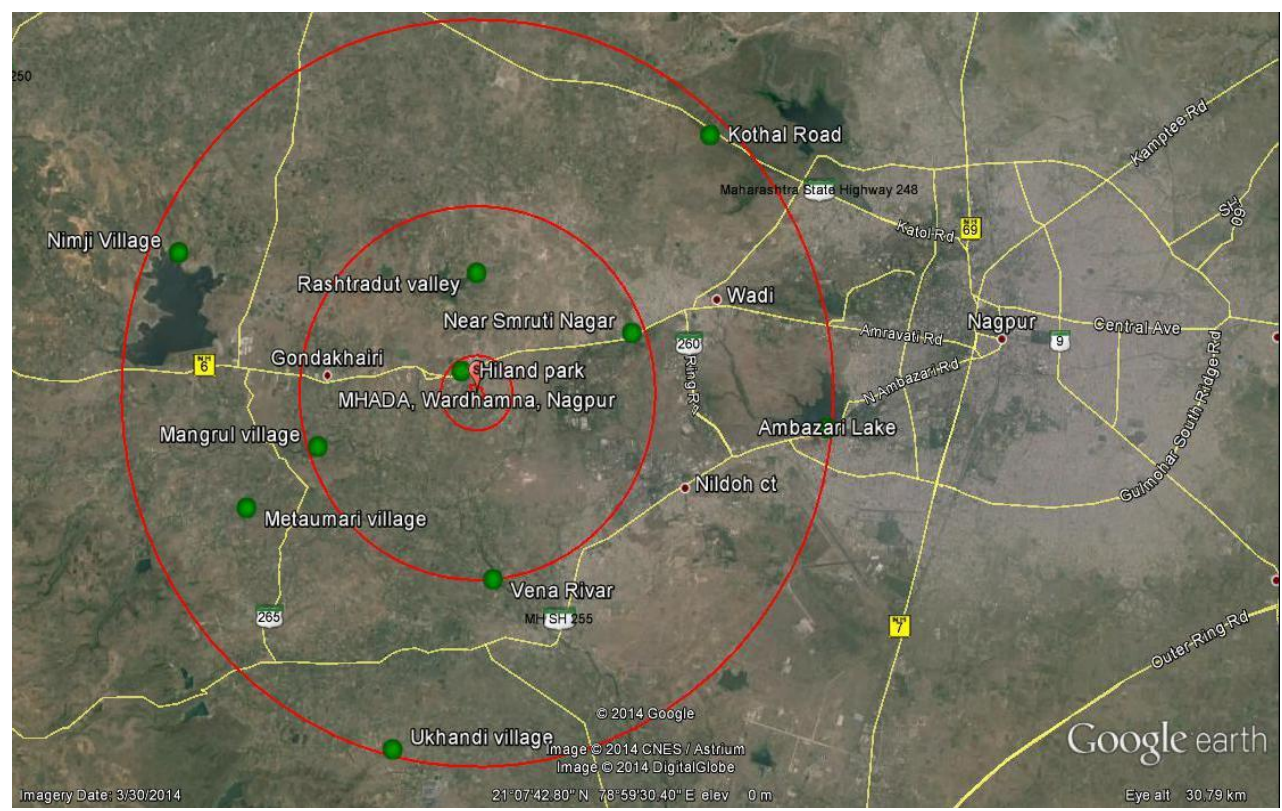

Fig. 2. Sampling locations for the project site.

\section{OBSERVATIONS}

All possible habitats and species of flora and fauna were observed in and around the site. This was undertaken by visiting all possible landscape features and areas in and around the site. These observations recorded are site, time and season specific However, the actual observation data was supported by the data obtained from sources like reports, research papers and literature survey. Following observations have been recorded at different sampling locations.

Habitat Survey: Habitat determines the diversity and distribution of flora and fauna in any given ecosystem. Actual field observation and Google earth were used to characterize and distinguish landscape diversity in the core and Buffer Area.

Approximate percentage of natural habitats or vegetation cover in the actual project site area: $0-5 \%$

Type of habitats in the project location: Urbanized, semi natural, low biodiversity landscape

Approximate percentage of natural habitats in $1 \mathrm{~km}$ radius range of the project: $5-10 \%$

Approximate percentage of natural habitats in $5 \mathrm{~km}$ radius range of the project: $10-15 \%$

Approximate percentage of natural habitats in $10 \mathrm{~km}$ radius 
range of the project: $15-20 \%$

Type of natural ecosystems:

1) Tropical Dry Deciduous Forests

2) Tropical Moist Deciduous Forests

3) Deciduous Forest

4) Mixed Deciduous Forests

5) Grassland and Scrublands

6) Degraded Scrublands

\section{A. Floristic Diversity}

This study was commenced to document diversity and density of herb, shrub, climber and tree species existing in the areas that fall within the core and Buffer Area. Literature survey was used to obtain background information about the local vegetation in the core and buffer area.

Following Fig. 3 represents the flora in Core and Buffer Area.

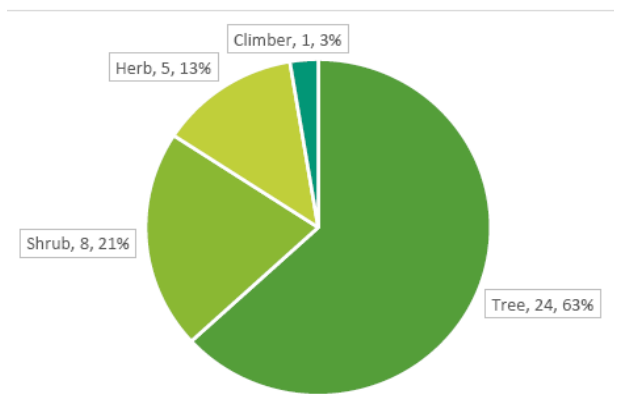

Fig. 3. Flora in the Core Area.

In Core Area, species found are mostly native and indigenous representing considerable vegetation diversity and ecological significance. Total of 38 species were observed as is evident from the figure above.

The Buffer Area falls between moderate dense forests to open to non forest areas. Overall 125 species of plants were observed in the area as is evident from the Fig. 4 below.

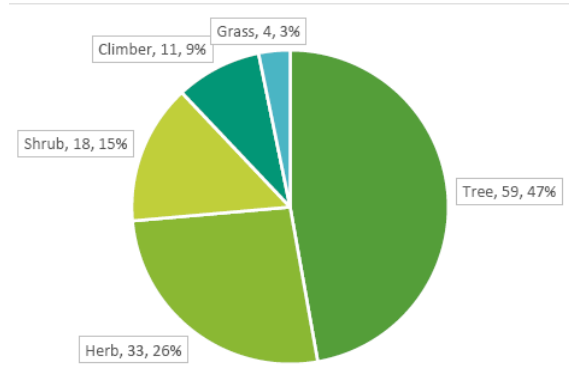

Fig. 4. Flora in the Buffer Area.

\section{B. Faunal Diversity}

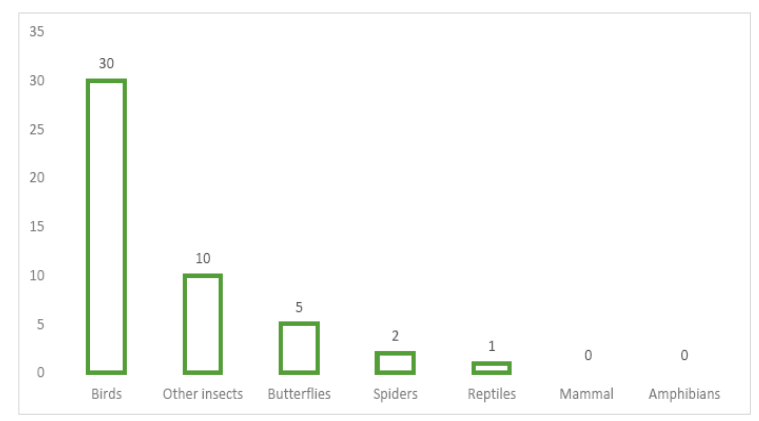

Fig. 5. Fauna observed in the Core Area.

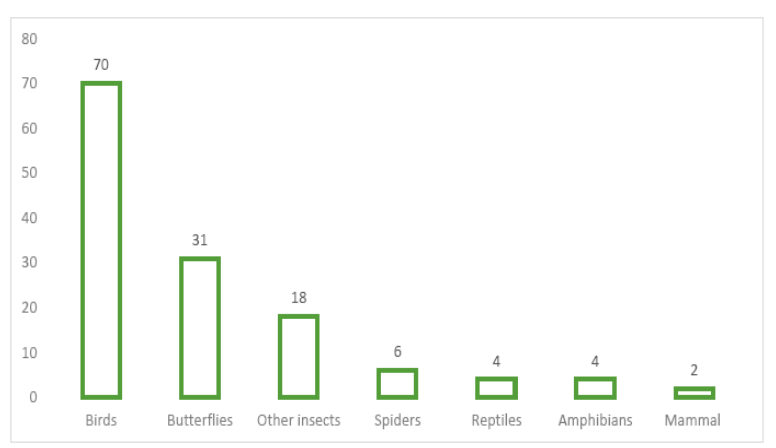

Fig. 6. Fauna observed in the Buffer Area.

In the core site, the faunal diversity was limited to a few common species of Birds, Butterflies, insects, rats and lizards. Good Avifaunal diversity was observed in the area surrounding the core site. There's a rare possibility of bigger mammals. A good diversity of Birds, Butterflies and other insects was observed in the buffer area due to the presence of forests patch.

Graphical representation of faunal diversity in the core and in the Buffer Area is evident from Fig. 5 and Fig. 6.

\section{VEGETATION AND BIODIVERSITY ANALYSIS}

Vegetation observed in $10 \mathrm{~km}$ area has a mixture of dry and moist deciduous type. Along the National Highway 3, dry to scrubby grasslands were observed. Looking at the climate and rainfall, the climax regions has presence of moist deciduous trees. The area experiences moist deciduous forest but due to years of intense intervention by human beings for agriculture and cutting for fuel wood etc. has degraded open habitats and few grassland. The dominant tree species in 10 $\mathrm{km}$ radius were Anogeissus latifolia, Haldina cordifolia, Lagerstroemia microcarpa, Lagerstroemia parviflora, Lannea coromandelica, Garuga pinnata, Azadirachta indica, Oroxylum indicum. The plant species like Erinocarpus nimmonii, Ficus asperimma, Miliusa tomentosa, Kydia calycina were seen in water bodies in the same area. Similarly, a good number and diversity of birds like Racket-tailed Drongo, White-bellied Drongo, European Roller, Oriental White-eye Buzzard, Eurasian Marsh Harrier, Crested Serpent Eagle were observed mainly in the areas of Bhatsa and Tansa Catchment regions. Some migratory birds like Jacobin Cuckoo, Blue Rock Thrush, Yellow-throated Petronia, and Europian Roller were also observed during the survey. A total number of 117 species of birds were found in this area.

Biodiversity in the township premises and surrounding is in degraded state due to years of human intervention. This can be said after assessing the protected areas in the district or surroundings, which has a mixture of dry and moist deciduous forest with great diversity of birds, insects and mammals etc. As per history, man cultivated the flat areas after cutting the original forest, so it destroyed the habitats for many faunal species. They either migrated to protected areas or vanished due to habitat loss. Species which could adapt to this newly developed habitat also known as 'generalist species' are commonly observed. Very few uncommon or endemic species are observed in the area under consideration. That little biodiversity which is the only natural raw material present in this area needs to be protected and nurtured which 
would consequently improve the quality of biodiversity.

\section{Sustainable RESIDENTIAL DEVELOPMENT}

This project aims to follow the policies and regulations related to the sustainable residential regulations in urban areas by practicing the following measures:

- Conservation of energy and other resources and employ measures to reduce their adverse effects on the environment.

- Provision of access to basic necessities such as transport, health, education, recreation and medical services.

- Adopting measures such as cycling, walking and public transport.

- Enhance and protect the natural heritage

\section{Mitigation MEASURES}

Ecological Restoration could be the only solution to save and improve the biodiversity. Barren areas on site shall be adopted to translocate by compensatory plantations. Plantations and insect-bird attraction gardens shall be constructed in order to improve the ecology of the area. Birds nest will be installed to create grounds for bird species. Water will be treated before discharge in to the local water bodies and waste shall be segregated and disposed as per the regulation. Dust, debris and waste will be managed as per the prescribed regulation. Noise level will be maintained to the prescribed level in order to prevent the adverse effects on the birds, mammal and other sensitive species in the area. Efforts will be taken by the proponent to slow down the speed of passing vehicles in order to prevent roadkills of animals. Experts will be consulted in order take steps to reserve the forest area and restoration of the degraded forest. The proponent also plans to undertake drives to initiate plantation in the area for restoration of barren and degraded landscapes.

\section{CONCLUSIONS}

The proposed project area is spread over plain land having mostly grasslands \& vegetation in clusters. Due to constant human interference, the floral and faunal habitats have been affected. The conditions on land can be improved using appropriate arrangement of plants \& selection of species, adopting suggested mitigation measures and by following the procedures and guidelines stated by Ministry of Environment and Forest (MoEF). This study shall also prove useful for site studies of similar topography. It should be noted that this study records the flora and fauna on the days of the site visit. It doesn't record the same that may appear on the other times of the year and which may not be evident at the time of the visit.

\section{ABBREVIATIONS}

EIA: Environment Impact Assessment

EMP: Environment Management Planning

FEE: Fine Envirotech Engineers

GIS: Geographic Information System

MoEF: Ministry of Environment and Forest, Government of India.

\section{REFERENCES}

[1] S. S. Negi, Biodiversity and Its Conservation in India, Indus Publications, New Delhi, 1993.

[2] M. Rai, P. Giradkar, M. Rathod, and A. Khurad, "Biodiversity: Colour pattern and butterfly diversity in tiger reserve in Tadoba National Park, Maharashtra," Life to Our Mother Earth, GM Offset Press, Chennai, pp. 65-74, 2006.

[3] E. Burton, M. Jenks, and K. Williams, The Compact City: A Sustainable Urban Form? Routledge, 2003.

[4] H. S. Hasibuan et al., "The role of transit oriented development in constructing urban environment sustainability, the case of jabodetabek, Indonesia," Procedia Environmental Sciences, vol. 20, no. 1, pp. 622-631, 2014.

[5] V. W. Maclaren, "Urban sustainability reporting," Journal of the American Planning Association, vol. 62, no. 2, pp. 184-202, 1996.

[6] Climate Modelling Forum, India's GHG Emissions Profile, Ministry of Environment and Forests, Government of India, New Delhi, India, 2009.

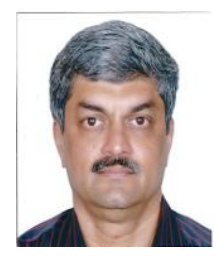

Umesh Kulkarni is born on March 12, 1964 in Mumbai, Maharashtra, India. He holds a doctorate in environmental science, master and bachelor degrees from the University of Mumbai, India.

$\mathrm{He}$ is currently the proprietor of M/s Fine Envirotech Engineers (FEE) at Mahim, Mumbai, India. FEE's consultancy services include but not limited to Environmental Impact Assessment Studies, Coastal Regulation Zone Projects, Lake Conservation and Restoration, Marine Ecosystem Studies, Solid Waste and Hazardous Waste Management, Environmental Management Plan, Disaster Management Plan and Risk Analysis, $\mathrm{He}$ has published research papers in Indian Journal of Environment, American Chemical society and Journal of Public Health.

Dr. Umesh Kulkarni was a member of Maharashtra Pollution Control Board, member of National Hydroelectric Power Corporation, founder member of national committee to form Bio-medical water rules holds membership with American Solid Waste Association, Indian Water Works Association, Water Environment Federation, Indian Institute of Environment Sciences, International Eco-Tourism Society, Associate Member-Indo Brazilian Society, Member-Maharashtra Economic Development Corporation (MEDC).

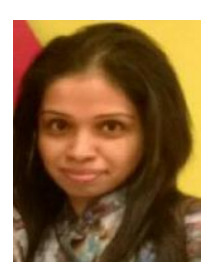

Manali Chalke was born on November 4, 1985 in Mumbai, Maharashtra, India. She holds master degree in environmental science specialized in pollution and monitoring from Brunel University, West London, United Kingdom in 2010 and bachelor degree in chemical engineering from University of Mumbai, India in 2007.

She is currently employed with Fine Envirotech Engineers as a corporate sustainability expert at Mumbai, Maharashtra, India. Her past experiences involve working as a senior environment engineer with Aquachem Enviro Engineers Pvt. Ltd. Mumbai, Maharashtra, India. As a product application specialist with Dorf Ketal Chemicals (I) Pvt. Ltd at Mumbai, Maharashtra, India. As a sustainability officer at Northwest London Hospitals, West London, United Kingdom. She has done internships with Atkins, United Kingdom and with Indian Institute of Technology, Mumbai, India.

Ms. Chalke holds membership with Chartered Institution of Water and Environmental Management and Chartered Institution of Wastes Management.

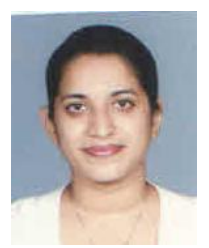

Rochelle Lobo was born on March 20, 1987 in Kuwait She holds a master degree in zoology in 2013 from Mumbai University, Post graduate diploma in environment science from University of Canterbury, New Zealand in 2010 and bachelor degree in zoology from Mumbai University in 2008.

She is currently employed with Fine Envirotech Engineers as an environmental expert at Mumbai, Maharashtra, India. Her work profile includes a wide array of skills relating to projects under the coastal regulation zone, terrestrial and marine biodiversity and sustainability studies, environment monitoring, disaster management plan, solid waste and hazardous waste management, environmental management plan, environmental impact assessment at state as well as at national levels. 